\title{
Factors for Resource Conservation in Present-Day Conditions
}

\author{
Anna Aleksandrovna Vershinina ${ }^{1 *}$, Olga Aleksandrovna Zhdanova ${ }^{1}$, Svetlana Vladimirovna Plyasova ${ }^{2}$, Knarik \\ Karapetovna Arabyan ${ }^{3}$

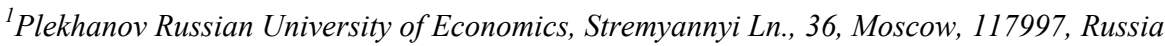 \\ ${ }^{2}$ Synergy Moscow University for Industry and Finance, Meshchanskaya St., 9/14, Moscow, 129090, Russia \\ ${ }^{3}$ Russian Presidential Academy of National Economics and Public Administration, Vernadsky Ave., 82, Moscow, 119571, Russia \\ *Corresponding author E-mail: vershinina.a.a@inbox.ru
}

\begin{abstract}
This paper puts forward and confirms the following hypothesis: at any level, resource conservation policy is grounded in a set of factors for resource conservation, which influence the achievement of target indicators. To confirm the hypothesis, the authors explore the concept of resource conservation and investigate the issue of effective and rational use of resources both at the level of production and consumption by particular entities and at the level of the national economy as a whole. The paper examines the role played by Russia in maintaining environmental security globally and explores some of the key challenges and threats to environmental security at the legislative level. The authors propose a classification of factors for resource conservation that could help employ relevant methods for managing resource conservation, reduce resource consumption, and achieve a better environmental situation.
\end{abstract}

Keywords: Ecology; Environmental security; factors for resource conservation; Resource conservation policy.

\section{Introduction}

In present-day conditions, despite serious changes in the geopolitical situation on the European continent and new foreigneconomic dissentions between Western economies and the Russian national economic system [1], environmental issues are common for all nations, with those of environmental security being a special concern. Negative changes in the environment, including those caused by man's intensifying impact on nature, are increasingly drawing the attention of the general public to environmental issues. Issues of poor ecology are of major concern to the government as well.

With today's rapid economic development and scientific/technical progress, increasing volumes of production, increasing volumes of production waste, and declining reserves of mineral resources, mankind is witnessing an exacerbation of tensions between nature and man. From theoretical and practical perspectives, added significance is getting attached to issues related to ensuring resource conservation and identifying sets of factors associated with it. In addition, to ensure a modernization breakthrough, it may help to bring together all of the nation's key resources - intellectual, human-resource, production, financial, and administrative, and to focus them on resolving the nation's primary objectives for innovation-driven development [2]. And, to ensure stability and sustainable economic growth, the government will need to ensure well-structured and seamless organization of the various areas of activity by the state [3].

In present-day conditions, there is growing interest in the issue of effective and rational use of resources both at the level of the national economy and at the level of production and consumption by individual entities. With that said, it, above all, is enterprises that are expected to take appropriate measures aimed at ensuring resource conservation by reference to relevant areas within the nation's economic/environmental policy. The economical and effi- cient use of resources in production facilities will help achieve top results at the level of the national economy as well.

\section{Methods}

A few words about the paper's theoretical and methodological bases. In writing this work, the authors relied on publications by Russian scholars on issues related to resource conservation and environmental policy. The work employs the dialectical method of inquiry, the systemic approach, a set of general research and special methods, including analysis, synthesis, analogy, and classification, as well as the historical and logical methods.

The work's information basis is Russian statutes on ecology, including documents regulating environmental protection and those dealing with strategies for national security and environmental security.

\section{Results}

\subsection{Gist of the Concept of Resource Conservation}

Resource conservation may be viewed as a process that implies cultivating such proportions among the resources used in production and consumption that will help boost the degree of satisfaction of existing needs through boosts in the amount of useful components derived from the resources used, while maintaining the environmental security of the nation, its ecosystem, its regions, its businesses, and its citizens [4].

In developing a policy of resource conservation at any level, it is important to identify a set of factors influencing the achievement of target indicators. Addressing these factors in a proper manner is a key resource conservation strategy. 


\subsection{Russia's Role in Maintaining Environmental Secu- rity}

Russia plays a crucial role in maintaining environmental security, as its vast territory houses a considerable part of the planet's biodiversity. Its immense intellectual, mineral-resource, and economic potential should make Russia a key player in resolving global and national environmental issues.

Over the past few years, Russia has passed a number of statutes aimed at helping resolve ecology-related issues, including the following:

- Resolution of the Government of the Russian Federation No. 322 'On Signing into Law a State Program of the Russian Federation Entitled 'Reproduction and Use of Natural Resources'" of April 15, 2014;

- Resolution of the Government of the Russian Federation No. 326

'On Signing into Law a State Program of the Russian Federation Entitled 'Environmental Protection for the Period 2012-2020' of April 15, 2014;

- Decree of the President of the Russian Federation No. 683 'On the Strategy for National Security in the Russian Federation' of December 31, 2015;

- Decree of the President of the Russian Federation No. 7 'On Celebrating the Year of Ecology in the Russian Federation' of January 5, 2016;

- Decree of the President of the Russian Federation No. 176 'On the Strategy for Environmental Security in the Russian Federation for the Period through to 2025' of April 6, 2017.

The year 2017 was officially declared the Year of Ecology in the Russian Federation. In January 2016, President V.V. Putin signed into law the decree 'On Celebrating the Year of Ecology in the Russian Federation'. This decision was made based on an analysis of long-time changes in the environment and by reference to recommendations from international environmental organizations and the latest trends in the development of the national economy and social sphere.

The understanding that present-day economics should not ignore the significance of environmental issues requires searching for ways to resolve these issues.

The Russian government came up with a Plan of Relevant Activities on Celebrating the Year of Ecology in Russia in 2017. The document provided for the conduct of special-purpose activities aimed at transforming people's mass consciousness with respect to dealing with the environment and natural resources. Furthermore, despite the Year of Ecology now being over, the government has continued to resolve the objectives of Russia's transition to a model of sustainable economic development inclusive of a focus on environmental issues.

Among the key areas for activity in this context are the following [5]:

- enhancing the regulatory framework regulating the sphere of ecology;

- shifting to the best technology available. The Year of Ecology plan features a few dozen environmental activities to be carried out by large enterprises in various regions of the country. With that said, there are plans to reduce pollutant emissions by over 70,000 tons per year;

- enhancing the waste management system. In 2017, there were plans to recultivate over 20 household waste landfills. In dozens of regions, there are now in place new waste sorting and waste processing complexes and waste treatment centers;

- expanding the nation's natural areas under special protection. There are plans to increase, within the next few years, the total area of federal natural areas under special protection by $18 \%$; - boosting the protection of water resources. The Year of Ecology plan includes over 70 activities aimed at protecting the nation's water resources, and there are plans to build a few dozen sites designed to reduce negative impact on water resources;
- boosting the protection of forest resources and implementing forest regeneration activities. In 2017, there were plans to restore several hundred thousand hectares of forest;

- boosting the protection of the animal world. Today, the authorities are continuing the implementation of a program for reintroduction of rare animal species into the natural environment;

- raising environmental awareness nationally and through regional programs. In accordance with its activities plan, in 2017 the Russian government carried out a set of nationwide and regional symposia for discussion of relevant issues in the area of environmental development, including various conferences, forums, and round tables. There were staged a number of environmental contests for high-school students, festivals, and conventions, photography exhibitions, and volunteer-led events.

With that said, among the key challenges and threats to environmental security established at the legislative level are the following [6]:

- increases in consumption of natural resources against a backdrop of declines in reserves thereof, which, amid economic globalization, is leading to rivalry for access to natural resources and having a negative effect on the state of national security in the Russian Federation;

- existence of populous areas characterized by high levels of environmental pollution and natural site degradation;

- high levels of pollution and low water quality in many water sites, degradation of the ecosystems of small rivers, and technogenic pollution of subterranean waters in areas occupied by major industrial enterprises;

- increased production and consumption waste volumes against a backdrop of insufficient levels of waste management;

- existence of numerous sites with accumulated harm to the environment, including areas subjected to radioactive and chemical contamination;

- high levels of wear and tear of plant and equipment at production facilities and poor progress in terms of technological modernization of the economy;

- poor performance in terms of development and implementation of eco-friendly technology;

- failure to make the intended use of the funding that comes into Russia's budgets by way of payment for negative impact on the environment and compensation for damage to the environment, administrative fines, and other types of environmental payments and taxes.

Based on the aforesaid, implementing a policy of resource conservation and environmental security is one of the key factors for sustainable development. There appears to be a growing need today to pursue a competent policy on issues of resource conservation.

\subsection{Internal and External Factors for Resource Conser- vation}

The authors' classification of factors for resource conservation is grounded in dividing them into internal (direct) and external (indirect) factors

Internal factors include technical, technological, organizational, and consumer factors

Technical factors have an effect with respect to drops in products' prime cost and boosts in their quality. This group of factors is associated with enhancing an enterprise's existing product and boosting the effectiveness of the use of resources (factors of production). It deals with the degree of focus on the following areas: price of resources; quality of resources; degree to which a resource can be substituted or supplemented; time for getting a resource to the place; potential and conditions for attracting a borrowed resource.

Technological factors come into play during the process of making a product. This group of factors deals with the degree of focus on the following areas: equipment's match with the latest standards; introduction of new equipment; modernization of existing 
equipment; boosts in the level of production automation; equipment's physical wear and tear and depreciation life; use of production capacities; length of the production cycle; volume, composition, and structure of resource consumption; share of non-material resources and non-material assets in the structure of consumption resources; distribution of the volume of resource consumption across the stages of production.

Organizational factors are aimed at enhancing the organization and structure of the process of production. This group of factors deals with the degree of focus on the following areas: enhancement of specialization; use of waste; share of recycled waste; assessment of effectiveness of the use of non-material resources and non-material assets; enhancement of the system of provision with material and non-material resources; enhancement of the product quality control system; system of managing resource consumption; staff structure, rotation, and qualification levels; personnel motivation system; system of economic responsibility for the irrational use of resources.

Consumer factors are associated with influence from consumers of the end product. This group of factors deals with the degree of focus on the following areas: an end product's price; size of demand for a product; a product's composition and structure; a product's useful (and shelf) life; irrational use of products purchased.

It is worth noting that internal factors depend on external ones, so of greater interest is classifying the latter.

External factors include economic, political, legal, educational, and environmental ones.

Economic factors form the widest category and include government regulation of resource conservation via tax policy, fiscal policy, monetary policy, investment policy, fuel/raw materials policy, and antimonopoly policy. In this context, worthy of a separate mention are government stimulation of resource-saving policy at enterprises through the use of tax concessions, investment tax credits, tax credits, and environmental taxes; subsidizing; government involvement in projects; state of infrastructure within the national economy; extent of competition in the market; government control over the use of fuel/energy resources. A key role in the implementation of resource-saving policy is played by programs of technical development of production activity [7], technology and knowledge transfer, and creation and implementation of low- and nonwaste technology. Thus, for instance, pursuant to Decree of the President of the Russian Federation No. 176 'On the Strategy for Environmental Security in the Russian Federation for the Period through to $2025^{\prime}$ of April 19, 2017, the mechanism underlying the implementation of government policy on ensuring environmental security incorporates: stimulating the implementation of the latest technology available, creating production and consumption waste storage, treatment, recycling, and sterilization facilities that meet the latest requirements and standards, as well as driving boosts in production and consumption waste reuse through subsidies, tax and tariff concessions, and other forms of support. In addition, a leading role in regulating scientific/technical potential is government support for its workforce component [8], while the rapid development of the financial market requires enhancing existing and putting in place new financial institutions [9].

Political factors, too, have a significant effect on resource conservation and include: customs policy in respect of foreign technology and equipment; export duties associated with the sale of natural resources; the nation's ability to wield influence in the international arena and the degree thereof; cooperating with foreign nations; taking part in international organizations; implementing joint (international) projects, including in the area of ecology; agreements in the area of environmental protection.

Legal factors are associated with political and economic ones and include: instituting statutory provisions and standards on resource consumption; instituting statutory provisions and standards on resource conservation; legal responsibility for violating environmental norms and polluting the environment. Since 2017, as part of the Year of Ecology program, increased control has been administered over the operation of large industrial enterprises throughout the country, which the government subjects to checks for compliance with environmental security standards. In the same year, the government brought into effect a set of amendments to laws dealing with waste disposal. Thus, for instance, today it is prohibited to bury waste that contains useful components (there is a special roster thereof established by the Russian government). Educational factors are aimed at enhancing the system of resource conservation and include augmenting the role played by the scientific organization of labor; boosting environmental literacy; and developing information technology.

Environmental factors are the conditions for implementing resource-saving policy and include the following: extent of environmental pollution; extent of harm to people's health and the environment from production; depletion of reserves of natural resources; natural/climatic conditions; production density; population density.

\section{Discussion}

Without question, implementing and employing resource-saving technology is the basis of any resource-saving policy. Russia's economic issues and complexities are reflected not only in slower production but in decreased production as well [10], and one of the best solutions to that is a solid resource-saving policy. With that said, in order to work out an effective resource-saving policy, it may help to have an idea of what factors for resource conservation are there and how they can be classified. On the one hand, these factors must be viewed in an integrated manner, and on the other hand, each factor's role and significance is largely dependent on the sector of the economy, the type of production, and the external environment.

Despite the importance of the role played in environmental development by government policy, success with implementing new waste management systems, implementing the latest technology available, conserving natural areas, conserving water and forest resources, developing the wildlife sanctuary system, and preserving biodiversity will also depend on the degree of economic responsibility on the part of economic entities. Thus, issues of resource conservation and those related to identifying the above factors are of an integrated nature and may require concerted effort from economic entities.

\section{Conclusion}

Taking account and making use of factors for resource conservation could help employ relevant methods for managing resource conservation, reduce resource consumption, and improve the environmental situation.

The paper introduces a classification of factors for resource conservation that differentiates between internal and external ones. Exploring these factors should help reveal, in a comprehensive manner, their significance and integrated nature.

The hypothesis put forward by the authors at the beginning of this work has been confirmed. The list of factors for resource conservation mentioned in this paper is by no means exhaustive and final Thus, for instance, among the organizational factors, more indepth research is needed with respect to human capital, which is quite a tough area, as what is subject to formalization and assessment is components of an emotional/psychological nature, which it is quite hard to assess in an objective manner [11]. In their future research, the authors intend to identify some other factors for resource conservation, as well as propose a system of indicators based on those factors that would enable quantitative assessments of the role of each factor in the implementation of resource conservation policy. 


\section{References}

[1] Maksimova TP, Problema prodovol'stvennogo obespecheniya RF v usloviyakh sanktsii [The issue of food security in a climate of sanctions]. In Sbornik materialov po itogam Vserossiiskoi nauchnoprakticheskoi konferentsii s mezhdunarodnym uchastiem "Regional'naya ekonomika:problemy i perspektivy razvitiya" [Proceedings of Regional Economy: Issues in and Prospects for Its Development: All-Russian Research-to-Practice Conference with International Guests], pp. 211-216. Makhachkala, Russia: Dagestan State University, 2014.

[2] Ustyuzhanina EV, Evsyukov SG \& Petrov AG (2013), Organizatsionnoe stroenie krupnykh korporatsii kak faktor stimulirovaniya (sderzhivaniya) ikh innovatsionnogo razvitiya [The organizational structure of large corporations as a factor in stimulating (impeding) their innovation-focused development]. Natsional'nye Interesy: Prioritety i Bezopasnost' 9(32), 10-32.

[3] Shuvalova EB, Solyarik MA \& Zakharova DS (2016), Nalogovye aspekty ekonomicheskoi bezopasnosti v Rossiiskoi Federatsii [Tax aspects of economic security in the Russian Federation]. Statistika Ekonomika 3, 51-54.

[4] Khansevyarov RI (2011), Resursosberezhenie kak faktor povysheniya effektivnosti proizvodstva [Resource conservation as a factor for improved production efficiency]. Ekonomicheskie Nauki $79,50-53$.

[5] EcoYear.ru (2017). http://ecoyear.ru/about/

[6] Ukaz Prezidenta Rossiiskoi Federatsii ot 19.04.2017 g. № 176 O Strategii ekologicheskoi bezopasnosti Rossiiskoi Federatsii na period do 2025 goda [Decree of the President of the Russian Federation No. 176 'On the Strategy for Environmental Security in the Russian Federation for the Period through to 2025' of April 19, 2017]. http://kremlin.ru/acts/bank/41879/page/1

[7] Bondarenko TG, Ishkinina GS, Khalidov IA \& Soltakhanov AU (2018), Developing methodological approaches to financial and economic planning at oil and gas enterprises. Espacios 39(19), p. 32 .

[8] Bondarenko NE (2013), Innovatsionnaya politika gosudarstva: Teoreticheskie aspekty realizatsii [The state's innovation policy: Theoretical aspects of implementing it]. Vestnik Altaiskoi Akademii Ekonomiki i Prava S1(32), 11-15.

[9] Vershinina AA, Goryainova LV, Zhdanova OA \& Maksimova TP (2016), State of the investment fund market as an indicator of the country's socio-economic development. Journal of Internet Banking and Commerce 21(S3).

[10] Baurina SB, Nazarova EV \& Savchenko EO (2017), The problem of ensuring industrial products quality in Russia. The Journal of Business and Retail Management Research 12(1), 206-214.

[11] Arabyan KK (2010), Metodika otsenki chelovecheskogo kapitala [A methodology for assessing human capital]. Vestnik Moskovskogo Universiteta MVD Rossii 8, 61-66. 